\title{
Doublespeak? Sustainability in the Arctic-A Text Mining Analysis of Norwegian Parliamentary Speeches
}

\author{
Mikko Moilanen * (D) and Stein Østbye (D) \\ School of Business and Economics, UiT The Arctic University of Norway, 9037 Tromsø, Norway; \\ stein.ostbye@uit.no \\ * Correspondence: mikko.moilanen@uit.no
}

Citation: Moilanen, M.; Østbye, S. Doublespeak? Sustainability in the Arctic-A Text Mining Analysis of Norwegian Parliamentary Speeches. Sustainability 2021, 13, 9397. https:// doi.org/10.3390/su13169397

Academic Editor: Lee Huskey

Received: 29 June 2021

Accepted: 18 August 2021

Published: 21 August 2021

Publisher's Note: MDPI stays neutral with regard to jurisdictional claims in published maps and institutional affiliations.

Copyright: (c) 2021 by the authors. Licensee MDPI, Basel, Switzerland. This article is an open access article distributed under the terms and conditions of the Creative Commons Attribution (CC BY) license (https:/ / creativecommons.org/licenses/by/ $4.0 /)$.

\begin{abstract}
This paper contributes to the recent literature on sustainability in the Arctic as a political concept. Parliamentary proceedings have increasingly been recognized as an important source of information for eliciting political issues. In this paper, we use unsupervised text mining techniques to analyze parliamentary speeches for Norway from the period from 2009 to 2016 to answer whether political coalitions talk differently about sustainability in the Arctic depending on being in opposition or government. We find that the difference between being in government and opposition, controlling for political label (left-right), is far more important than the difference between left and right, controlling for role (opposition-government). The results suggest that in the trade-off between political preferences and election success, the balance is tilted in favour of the latter. Our interpretation is that opportunistic behavior seems to dominate partisan behavior in the politics related to sustainability in the Arctic.
\end{abstract}

Keywords: text mining: sustainability; arctic; partisan theory

\section{Introduction}

Do political parties talk differently about sustainability in the Arctic and differently depending on being in opposition or government? In this paper we throw some light on these questions using text-based quantitative analysis of parliamentary speeches for Norway from the period 2009 to 2016.

Sustainability in the Arctic is an issue of increasing concern. Climate change is particularly rapid and noticeable in the Arctic, and is by far the greatest threat to nature and biodiversity [1,2]. Large Arctic sea areas that were previously covered by ice in the summer are becoming increasingly accessible. Climate change is leading to an increase in temperature across the globe, but the increase is two to three times faster in the Arctic than the global average. The warming is leading to melting ice and permafrost and changed living conditions for people living there, but also threatening living conditions elsewhere through rising sea levels and increased political tensions due to global geopolitical competition as the Arctic becomes more accessible and interesting from a commercial point of view [3]. Since 1980, the amount of ice in the Barents Sea has been reduced by as much as 50 percent. If this trend continues, the Arctic oceans may be completely ice-free in summer by 2050 .

Our choice of Norway as a case is not random. A greater proportion of the population in Norway is living north of the Arctic Circle (9 per cent) than in any other country in the world. Most of Norway's sea areas are north of the Arctic Circle [4], and as much as 80 per cent of all shipping in the Arctic passes through Norwegian waters. Norway is a vanguard country in implementing sustainability as a major guideline for authorities; the first national sustainability strategy was implemented as early as in 2002, and it has been updated several times. The UN Sustainable Development Goals and the Paris Agreement also provide overall direction for Norway's Arctic policy [4]. Although it has an ambitious sustainability policy, it is at the same time a major exporter of fossil fuels. Norway therefore 
faces a serious political dilemma that seems impossible to resolve and make it particularly tempting to substitute rhetoric for political action.

The substantial motivation for this research is to clarify how the concept of sustainability in the Arctic is actually used in a political context. As the popularity and usage of the sustainability concept has increased dramatically over the years, so has the confusion regarding the content to the extent that the concept now sometimes is used to defend diametrically opposed political positions [5]. Already in 2006, Jim MacNeill, the general secretary of the Brundtland commission and the lead author of Our common Future, wrote that "I no longer shock easily but to this day I remain stunned at what some governments in their legislation and some industries in their policies claim to be 'sustainable development'. Only in a Humpty Dumpty world of Orwellian doublespeak could the concept be read in the way some would suggest" [6] (George Orwell's "1984" uses the concept of "Newspeak". This is a government-invented language and is used by ministries that do the exact opposite of what their names imply, i.e., the Ministry of Truth is the ministry of propaganda and the Ministry of Plenty concerns itself with starvation [7]).

For politicians, deploying the sustainability concept can be a relatively low-cost way to indicate a responsible use of ecological, economic, and social resources, as it is difficult to observe the actual attainment of this goal [8]. The concept is also semantically flexible and positively connoted [9]. In addition, the concept's policy delivery is not only difficult to observe for voters, but also to evaluate [10]. The concept therefore suits well for political "greenwashing", when politicians pretend to place sustainability concerns on top of their agenda, but in reality prioritize other priorities first $[11,12]$. Stoknes and Rockström [13] define greenwashing as 'talking about reducing climate emissions and other environmental impacts, while simultaneously pushing for as much conventional economic and job growth as possible' (p. 42). Stevenson [14] states that the concept of bullshit best captures the inconsistencies we observe in climate governance. Giddens [15] refers to this phenomenon as a 'bandwagon effect'.

Aardal [16] found, using content analysis as a method, these tendencies in Norwegian party manifestos already 30 years ago. The parties tried to link environmental policy to issues where they already had a special commitment by adapting the environmental issues to their own core issues and their traditional political platforms. Jensen [17] has more recently used the Norwegian debate on petroleum extraction in the Barents Sea as a case study of doublespeak and used the concept of discourse co-optation to describe how Norway's 'drilling for the environment' discourse hollows out the environmentalist discourse, turns its logic upside down, and maintains Norway as a sustainable actor in the Arctic.

The theoretical motivation for framing the research question according to party lines (left-right) and position (government-opposition) is the long-standing idea that political parties face a trade-off between political preferences and preferences for winning next election, which goes back at least to the influential article by Hibbs [18], introducing the partisan model as a reaction to purely opportunistic models and exemplified by the famous model presented by Nordhaus [19]. A rather recent and extensive survey of this literature, containing close to 300 references, is offered by Dubois [20].

Recognizing that language is central to the study of politics is not new. After all, much of politics is expressed in words and semantics may have real effects on the economy and society. The potential impact of semantics has attracted more attention in economics recently in part due to the rise of behavioral economics and in part due to what has been called narrative economics [21]. The methodological motivation for using text-based quantitative analysis is the tremendous advancements in computational possibilities through machine-learning techniques and large digitized data sets (for methods in automated content analysis of political speeches, see the review by [22,23] and for surveys in sociology and political science, and [24] in economics). To the best of our knowledge, these methods have not been exploited in studies related to Arctic issues. 
Although our study is confined to Norway, it is important to emphasize that our approach and data code would easily be possible to adapt and apply to other Arctic countries since digitized datasets for parliamentary proceedings are now available for many countries including Canada, Iceland, Sweden, and Finland. This would allow future comparative circumpolar research on the issues we are addressing and make it possible to extend the analysis by considering for example cross-country variation in institutional setups.

The rest of this article is organized as follow. In Section 2 we provide a brief background for the analysis. The data and research methods are presented and discussed in Section 3, followed by results in Section 4. Section 5 contains the discussion based on results. Section 6 concludes and gives some suggestions for future research.

\section{Background}

The concept of sustainability has increasingly been used following the Brundtland Commission [25], defining 'sustainable development' as 'meeting the needs of the present without compromising the ability of future generations to meet their own needs'. This is basically an eloquent description of inter-generational Pareto-optimality combining economic development and environmental concerns. The beauty of the Pareto optimality principle is that it is difficult to disagree with, which may be part of the story when explaining why the concept initially was adopted and started to spread.

The increased popularity of the concept as witnessed by use in the news in Norway over the years is illustrated in the right panel of Figure 1, also reflecting the general public's awareness of this issue. The left panel of Figure 1 shows that sustainable development has experienced a rise to political prominence also in Norway, as measured by the use of sustainability words among members of parliament in our study period.
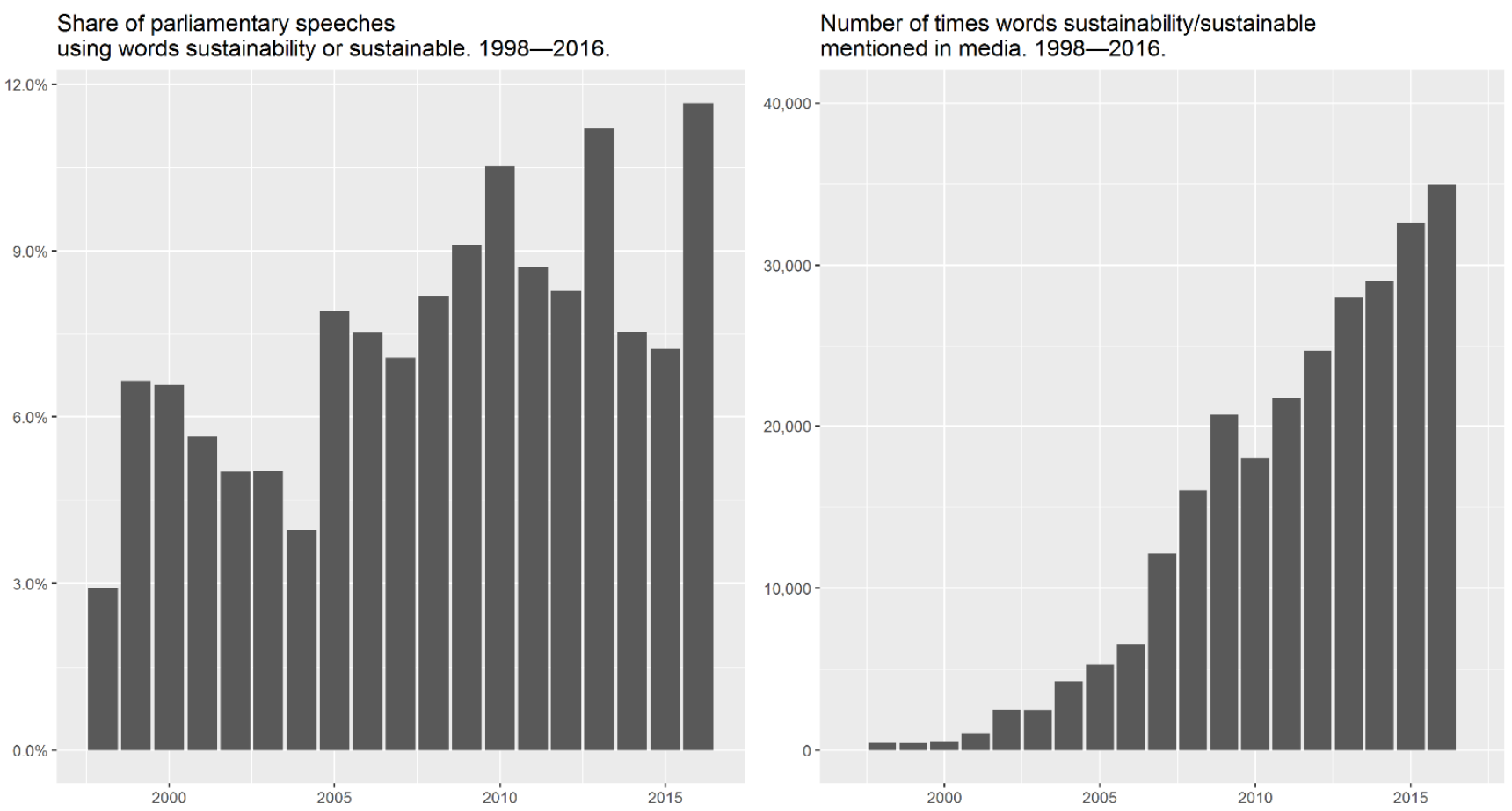

Figure 1. Usage of words sustainable or sustainability in parliamentary speeches and media in Norway. 1998-2016. Sources: Parliamentary speeches: Talk of Norway; Media: Retriever. 
As long as the concept was related to a highly aggregate level (present generation versus future generations), the consensus seems to have been widespread. However, as the concept has been translated into more operational terms at a more disaggregate level for political as well as policy purposes where 'a wider and wider array of entities and phenomena appears as objects of sustainability' [5] (p. 3), the usage has exploded, and the harmony has been difficult to maintain as conflicts of interests have become more visible.

Our data consists of digitized transcribed parliamentary speeches. The availability of data and development of tools to analyze the data have clearly been important for the increased interest in parliamentary debates as a source of information among political scientists, linguists, computer scientists, and others. But there are also more substantial arguments offered in favour of this line of research. Members of parliament invest a lot of time and resources on preparing and delivering parliamentary speeches, suggesting that parliamentary proceedings represent an important institution for producing policies in a democracy. It is therefore not 'just talk', but also a potentially valuable source of information from a policy perspective The average Norwegian MP gives about 100 speeches over a parliamentary period of 4 years [26] (p. 1).

Parliamentary systems vary across countries. It therefore seems necessary to say a few words about the Norwegian system. Norway has a unicameral parliament (Stortinget) where members are elected for a fixed period of four years. Hence, dissolution of parliament is not possible, forcing parties to find majorities that are tolerated by the majority in order to avoid crisis of government. The electoral system is based on proportional representation in 19 electoral districts. Election lists are party-based so a voter may only vote for one party-list. These features have led to a parliamentary system where parties have a lot of power but also a lot of responsibility to find workable solutions. Cabinets are typically formed by majority coalitions (as the period in our data prior to the election in 2013) or minority coalitions with support from other parties (as the period after the election in 2013).

The specifics related to the Norwegian parliamentary system, mentioned above, have implications for parliamentary debates as an institution. In the international literature, formal theory is centered around conflicting interests between party leaders and individual members in the parliament, modelled as a delegation game (see [27]). This is not a priority in a Norwegian context with exceptionally weak personal vote-seeking incentives. Other issues should rather be in the foreground, such as conflicting interests between the coalition and a member party. A party should favour a good election result for the coalition it belongs to. At the same time, it should also favour a good result for itself to increase power in the bargaining over the composition of the cabinet after election. The two things are not necessarily the same.

For our purpose, it seems sufficient to let theoretical considerations enter through the choice of dimensions visible in the two-by-two design (illustrated in Table 1), alluded to in the introduction. On the one hand, the left-right partisan dimension reflecting political preferences. On the other hand, the government-opposition dimension that may reveal something about opportunistic behavior. Although we are not doing a controlled experiment, we may think by analogy about our design as an experimental design and have referred to the different cases as 'treatments' in Table 1. Already this simple framework allows for multiple comparisons in the empirical analysis that will be developed in the next section.

Table 1. The framework for the empirical analysis.

\begin{tabular}{lccc}
\hline & & \multicolumn{2}{c}{ The Partisan Dimension } \\
\hline \multirow{2}{*}{ The power dimension } & Left & Right \\
\cline { 2 - 4 } & Government & Treatment 1 & Treatment 2 \\
\cline { 2 - 4 } & Opposition & Treatment 3 & Treatment 4 \\
\hline
\end{tabular}




\section{Data and Research Methods}

In this paper, we use structural topic modelling (STM), an unsupervised machine learning text processing technique [28]. Our aim is to analyze whether political parties use sustainable and sustainability terms differently when in position or opposition when discussing different Arctic issues. STM allows us to discover latent topics in a large set of parliamentary speeches and estimate their relationship to political parties, by detecting word patterns within speeches, and automatically identifying latent topics [28].

Topic modelling has increasingly been used to analyze parliamentary speeches. A recent discussion and systematic review of topic modelling and other approaches of text analysis applied to parliamentary proceedings can be found in [26,29]. In Norway, topic modelling has been recently used to analyze politicians' change of their rhetoric; Finseraas [30] found that MPs facing high political costs of climate policies tried to avoid to talk about environmental topics when the oil price declined.

\subsection{Data Retrieval and Reprocessing}

Our initial data set is The Talk of Norway data set, a collection of the digitized records of speeches of the MPs from the Norwegian Storting (Parliament) from 1998 to 2016 [31], appended by a large set of metadata variables. The data is openly accessible from the Talk of Norway Github repository. For this study, we restricted our sample to the speeches from the two last parliamentary periods, 2009-2013 and 2013-2016. As our goal is to study Arctic issues, we limited our sample to the speeches that had the following words in them, see Table 2.

Table 2. The words used to filter the subsample. The term in Norwegian in round brackets.

\begin{tabular}{cccc}
\hline Nordland (county) & Polar & $\begin{array}{c}\text { High North } \\
\text { (Nordområdene) }\end{array}$ & $\begin{array}{c}\text { Northern Norwegian } \\
\text { (Nordnorsk) }\end{array}$ \\
\hline Troms (county) & Barents & $\begin{array}{c}\text { Northern Norway } \\
\text { (Nord-Norge) }\end{array}$ & $\begin{array}{c}\text { North Calotte } \\
\text { (Nordkalotten) }\end{array}$ \\
\hline Finnmark (county) & $\begin{array}{c}\text { Circumpolar } \\
\text { (sirkumpolar) }\end{array}$ & Svalbard & \\
\hline The Arctic (Arktis) & Arctic (arktisk) & & \\
\hline
\end{tabular}

Our final data set consists of 3401 speeches. We extracted nouns and adjectives from the speeches to be used in our analysis. In addition, we also extracted compounds of adjectives and nouns which follow one another, using the Rapid Automatic Keyword Extraction (RAKE) method [32]. To reduce the computational load, we only used words that appeared at least in five speeches in our structured set of all analyzable speeches (called the corpus in linguistics).

\subsection{Method}

STM is a probabilistic topic modelling method, where each speech can load (more or less) on each topic. Topic coverage and word distribution are approximated with Bayesian inference [28,33]. STM is an extension of probabilistic topic models such as latent Dirichlet allocation [34] and correlated topic models [35]. In STM, documents (speeches) are composed of multiple topics. The proportions of the topics sum to 100 per cent over all topics in a speech. A topic is thus a probability vector over the words in the vocabulary (the vocabulary in our analysis consists of the nouns in the speeches). All terms are therefore potentially present in all topics, albeit with different weights [28].

We employ STM as this, unlike other topic models, can incorporate metadata in the analysis. In this paper, we connect speeches to information on whether the representant belongs to the left- or right-wing coalition and whether the coalition is in position (government) or opposition. We enter this covariate in the model in two ways: we allow both the partisan dimension (left-right) and the power dimension (position-opposition) to affect 
the frequency for a topic discussed. More importantly for this analysis, we also let these covariates affect how a topic is discussed (its content). The model is graphically illustrated in Figure 2 (see Supplementary for more details). We use the R package stm [28] in our analysis.

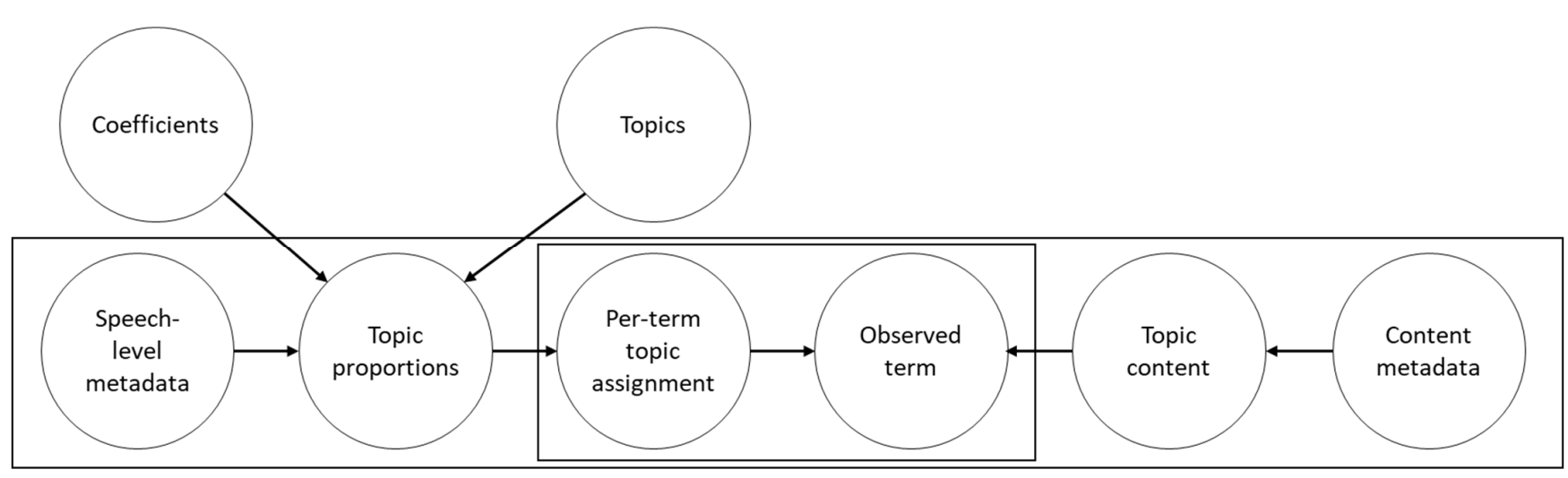

Figure 2. A graphical illustration of the structural topic model (following [33]). Note: Symbols and notation are explained in more detail in Supplementary.

\section{Results}

The number of topics that are related to the corpus of speeches is not known and must be estimated. We let the data and the computer algorithms decide the topic structure in the speeches and implement the spectral configuration [28] (p. 9) in stm. This approach resulted in 88 topics. To identify the topics where sustainability played an important role, we searched terms that included either sustainable or sustainability among the top 100 loading words in each topic. In this way, we identified 10 Arctic topics with important sustainability issues. The names assigned to each topic is where the human touch enters. The topic names are based on our interpretations of the set of terms that underlie each topic. Table 3 is showing the topics and the top seven loading terms for each topic.

Aardal [16] found that the parties adapted the environmental issues to their own core issues and their traditional political platform. We can use the topic modelling method to detect whether there are any core topics for the Arctic among the above sustainability topics. To find out how much the MPs talk about these topics in their speeches when in government, we calculated so-called topic proportions [28] (p. 2). Remember that a speech is a mixture of topics. The sum of the topic proportions across all topics for a speech is thus equal to $100 \%$. Similarly, topic proportions across all the speeches must add to $100 \%$. Figure 3 shows the topic proportion distributions by coalition when in office. We are thus able to identify four main core issues, i.e., the topics that have highest topic proportions, for both coalitions. The right-wing coalition talks most about ocean management plan, business development, petroleum politics, and Svalbard. Left-wing coalition MPs focus most on reindeer-husbandry agreement, business development, ocean management plan, and agreements with $E U$. We also find these topics, or Arctic core issues, in their government declarations (The Sundvollen platform [36] for the right-wing coalition and the Soria Moria II declaration [37] for the left-wing coalition). 

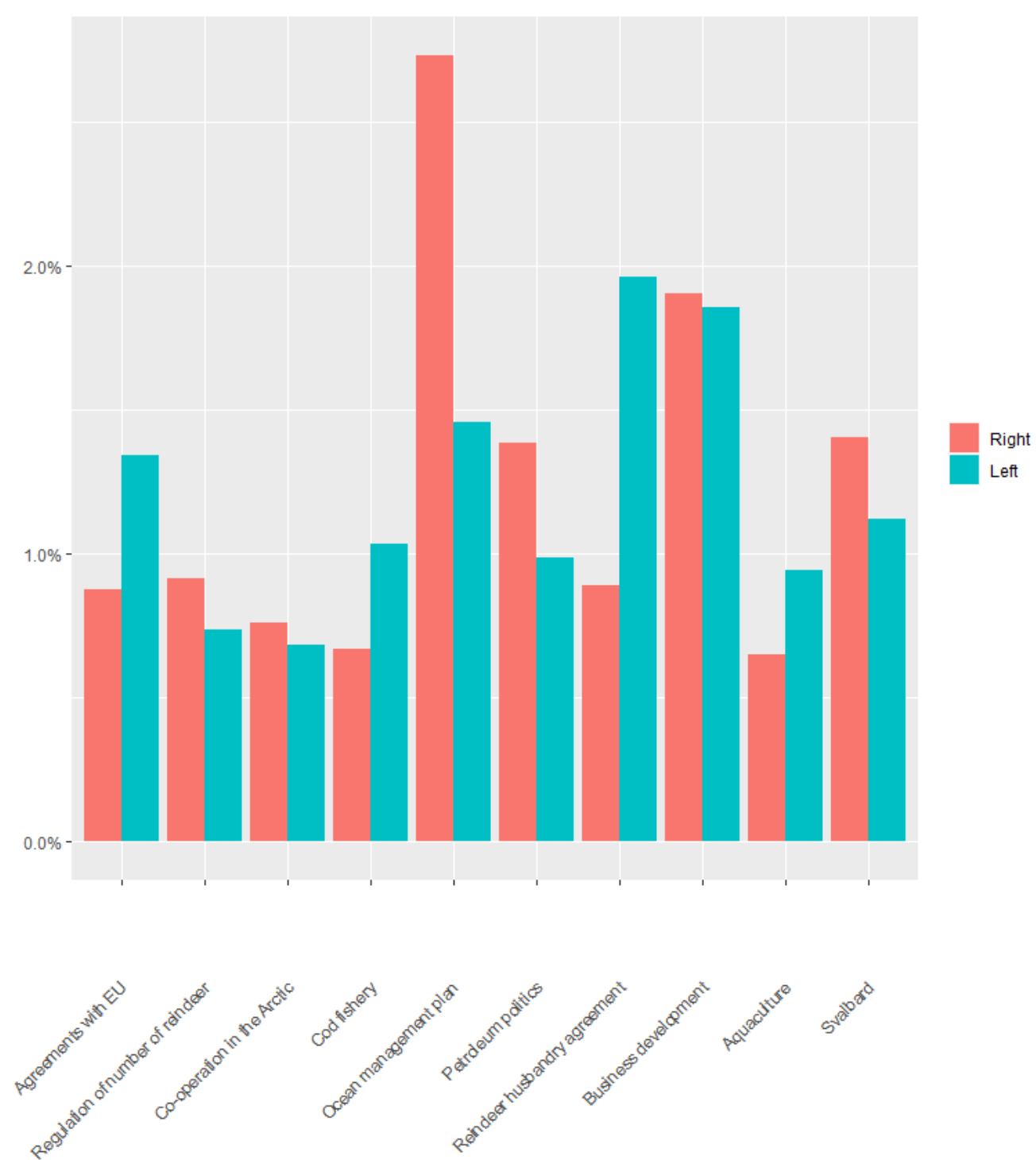

Figure 3. Topic proportions of sustainability topics when in office, by coalition.

In order to find out how sustainability is discussed within a topic and whether its usage is affected by being in government, we extracted all the terms including words sustainable/sustainability from the speeches, see the terms in Table 4 . We also calculated their log probabilities to belong to a specific topic. To control for time trends in the usage of sustainability terms, we adjusted the log probabilities of the sustainability keywords for the 2009-2013 period to be comparable with the 2013-2016 period by weighing the keywords by their use in national media. We used the Retriever electronic database to map the use of these terms in Norwegian media in these periods. 
Table 3. Topics and the most important terms within topics.

\begin{tabular}{|c|c|}
\hline Topic & Important Terms \\
\hline Agreements with EU & $\begin{array}{c}\text { The European Economic Area Agreement, EU countries, bilateral agreement, EEA } \\
\text { grants, billion Euro, legislative act, Norwegian interests }\end{array}$ \\
\hline Regulation of number of reindeer & $\begin{array}{c}\text { domesticated reindeer, industry, Minister of Agriculture, slaughter, reindeer owner, } \\
\text { reindeer grazing district, marketing }\end{array}$ \\
\hline Co-operation in the Arctic & Arctic, secretariat, coastal state, Greenland, indigenous peoples, Canada, observer \\
\hline Cod fishery & marine, coastal cod, ecosystem, catch, spawning stock, protection, stock situation \\
\hline Ocean management plan & $\begin{array}{c}\text { management plan, precautionary principle, ice edge, sea areas, southeast, polar } \\
\text { front, oil drilling }\end{array}$ \\
\hline Petroleum politics & $\begin{array}{c}\text { deposit, Norwegian oil, petroleum policy, impact assessment, the parties, the } \\
\text { directorate, start-up }\end{array}$ \\
\hline Reindeer husbandry agreement & $\begin{array}{l}\text { ecological sustainability, reindeer husbandry agreement, reindeer husbandry, } \\
\text { practitioner, reindeer husbandry industry, upper limit of number of reindeer, } \\
\text { Sami culture }\end{array}$ \\
\hline Business development & oil company, large industry, coal, Goliath, mining, petroleum industry, oil price \\
\hline Aquaculture & fish farm, indicator, location, minimum, use, environmental, closed \\
\hline Svalbard & $\begin{array}{c}\text { wilderness nature, Longyearbyen, archipelago, treaty, Svalbard policy, coal mining, } \\
\text { permanent enforcement }\end{array}$ \\
\hline
\end{tabular}

Table 4. Terms that included either words sustainable or sustainability in our subsample of speeches.

\begin{tabular}{cccc}
\hline sustainability & sustainable harvest & sustainable utilization & cultural sustainability \\
\hline sustainable & sustainable way & $\begin{array}{c}\text { sustainable } \\
\text { development }\end{array}$ & $\begin{array}{c}\text { ecological } \\
\text { sustainability }\end{array}$ \\
\hline sustainable use & sustainable level & sustainable growth & $\begin{array}{c}\text { ecologically } \\
\text { sustainable }\end{array}$ \\
\hline $\begin{array}{c}\text { sustainable } \\
\text { management }\end{array}$ & $\begin{array}{c}\text { sustainable reindeer } \\
\text { husbandry }\end{array}$ & sustainability strategy & $\begin{array}{c}\text { economic } \\
\text { sustainability }\end{array}$ \\
\hline
\end{tabular}

We now turn our attention to exploring whether the political coalitions use sustainability words "opportunistically", i.e., differently when in opposition and opposition, specifically focusing on the coalitions' core issues identified above. We measure this opportunism in two ways: by measuring difference in the probability of sustainability terms within topics between the coalition being in opposition or position, and by measuring differences in the content of sustainability words in topics between opposition and position.

Table 5 shows the total sum of log probabilities of sustainability terms within every topic (columns (1)-(4)) and how these probabilities differed between party sides being in opposition or position (columns (5)-(8)), together with topic proportions (columns (9) and (10)). 
Table 5. Sums of sustainability term probabilities and ratios of sustainability term probabilities by topic.

\begin{tabular}{|c|c|c|c|c|c|c|c|c|c|c|}
\hline & \multicolumn{4}{|c|}{$\begin{array}{l}\text { Sum of Sustainability } \\
\text { Term Probabilities }\end{array}$} & \multirow[b]{2}{*}{$\begin{array}{c}\text { In } \\
\text { Position }\end{array}$} & \multirow[b]{2}{*}{$\begin{array}{c}\text { In } \\
\text { Opposition }\end{array}$} & \multicolumn{2}{|c|}{$\begin{array}{c}\text { Ratio of Sustainability } \\
\text { Term Probabilities }\end{array}$} & \multicolumn{2}{|c|}{$\begin{array}{c}\text { Topic } \\
\text { Proportions }\end{array}$} \\
\hline & In Po & ition & In Opp & ssition & & & Left & Right & Left & Right \\
\hline & $\begin{array}{l}\text { Right } \\
(1)\end{array}$ & $\begin{array}{l}\text { Left } \\
(2)\end{array}$ & $\begin{array}{l}\text { Right } \\
(3)\end{array}$ & $\begin{array}{l}\text { Left } \\
(4)\end{array}$ & $\begin{array}{l}\text { Left/ } \\
\text { Right } \\
\text { ratio } \\
(5)\end{array}$ & $\begin{array}{l}\text { Left / Right } \\
\text { ratio } \\
(6)\end{array}$ & $\begin{array}{l}\text { Position/ } \\
\text { opposition } \\
\text { ratio } \\
(7)\end{array}$ & $\begin{array}{l}\text { Position/ } \\
\text { opposition } \\
\text { ratio } \\
(8)\end{array}$ & (9) & (10) \\
\hline $\begin{array}{l}\text { Agreements } \\
\text { with EU }\end{array}$ & 0.0037 & 0.0013 & 0.0027 & 0.0054 & 0.35 & 1.99 & 0.24 & 1.35 & $1.3 \%$ & $0.9 \%$ \\
\hline $\begin{array}{l}\text { Regulation of } \\
\text { number of } \\
\text { reindeer }\end{array}$ & 0.0130 & 0.0160 & 0.0101 & 0.0062 & 1.23 & 0.62 & 2.57 & 1.29 & $0.7 \%$ & $0.9 \%$ \\
\hline $\begin{array}{l}\text { Co-operation } \\
\text { in the Arctic }\end{array}$ & 0.0034 & 0.0035 & 0.0010 & 0.0021 & 1.03 & 2.22 & 1.65 & 3.56 & $0.7 \%$ & $0.8 \%$ \\
\hline Cod fishery & 0.0375 & 0.0069 & 0.0026 & 0.0115 & 0.18 & 4.47 & 0.60 & 14.61 & $1.0 \%$ & $0.7 \%$ \\
\hline $\begin{array}{c}\text { Ocean } \\
\text { management } \\
\text { plan }\end{array}$ & 0.0028 & 0.0017 & 0.0009 & 0.0014 & 0.61 & 1.59 & 1.19 & 3.12 & $1.5 \%$ & $2.7 \%$ \\
\hline $\begin{array}{l}\text { Petroleum } \\
\text { politics }\end{array}$ & 0.0017 & 0.0005 & 0.0003 & 0.0013 & 0.30 & 4.01 & 0.40 & 5.19 & $1.0 \%$ & $1.4 \%$ \\
\hline $\begin{array}{c}\text { Reindeer } \\
\text { husbandry } \\
\text { agreement }\end{array}$ & 0.0185 & 0.0248 & 0.0841 & 0.0189 & 1.34 & 0.22 & 1.31 & 0.22 & $2.0 \%$ & $0.9 \%$ \\
\hline $\begin{array}{c}\text { Business } \\
\text { development }\end{array}$ & 0.0033 & 0.0047 & 0.0018 & 0.0015 & 1.42 & 0.85 & 3.12 & 1.86 & $1.9 \%$ & $1.9 \%$ \\
\hline Aquaculture & 0.0035 & 0.0300 & 0.0015 & 0.0021 & 8.69 & 1.34 & 14.64 & 2.26 & $0.9 \%$ & $0.6 \%$ \\
\hline Svalbard & 0.0041 & 0.0010 & 0.0004 & 0.0003 & 0.26 & 0.79 & 3.74 & 11.49 & $1.1 \%$ & $1.4 \%$ \\
\hline
\end{tabular}

We can observe large differences in how the coalitions use the sustainability terms in their core issues when in office and in opposition (see columns (7) and (8)). For the right-wing coalition, we see that there is a clear increase in the ratio of probabilities of sustainability term usage in position and opposition: ocean management plan (3.12 times more frequent), business development (1.86), petroleum politics (5.19), and Svalbard (11.49). The tendency to talk more about sustainability in core issues is less clear for the left-wing: reindeer-husbandry agreement (1.31), business development (3.12), ocean management plan (1.19), and agreements with EU (0.24) We also see large increases in a few other topics., When discussing the cod fishery topic, it is over 14 times more likely that the right side mentions sustainability terms when governing than in opposition, while the left wing's probability to use sustainability terms in aquaculture topic when governing was 14 times higher than in opposition. Interestingly, the right-wing's probabilities to speak about sustainability in opposition are very low in every topic, except for reindeer husbandry agreement (see column (3)).

When it comes to the power dimension, we see in column (5) that the largest differences in how much parties use sustainability terms in government are in aquaculture: the left-wing uses these terms with almost nine times higher probability than the right wing when governing. The right-wing, on the contrary, is over five times more likely to mention sustainability terms related to cod fishery.

Above we could see that there are differences in how much left and ring wing coalitions use sustainability terms, both in their core issues and other topics. But do left- and rightwing coalitions also talk differently about sustainability? We can elicit this by measuring 
differences between opposition and position in the content of sustainability terms for each topic. To measure the differences in the sustainability term vocabulary (the way sustainability is talked about), we compute the pairwise cosine similarity (CS), which is often used to measure similarity in automated content analysis [38]. (Cosine similarity is measured by the cosine of the angle between the probability vectors (which measure the topics) and determines whether two vectors are pointing in roughly the same direction. The cosine similarity can be represented as $\frac{A \cdot B}{\|A\|\|B\|}$ where $A$ and $B$ are the term probability vectors of a topic for a coalition in office and in opposition). We calculate the pairwise CSs between the vocabulary distributions for four different situations: (i) Left in position and Right in position (treatment 1 vs. treatment 2 in Table 1), (ii) Left in opposition and Right in opposition (treatment 3 vs. treatment 4), (iii) Left in opposition and Left in position (treatment 3 vs. treatment 1 ) and (iv) Right in opposition and Right in position (treatment 4 vs. treatment 2). CS close to one indicates that usage of sustainability words is very similar, while a low CS indicates big difference in how sustainability words are used.

Table 6 (columns (3) and (4)) reveals that both for the right and left wing the content of sustainability terms is most dissimilar between opposition and position in the topics agreements with EU, petroleum politics and Svalbard. This indicates that the coalitions change the way they speak about sustainability in these issues when in office. Otherwise, the cosine similarities in column (3) and (4) are high implying that the usage of the sustainability terms in these topics does not change much, regardless of whether the coalitions are in position or opposition.

Table 6. Cosine similarities between the sustainability term distributions by topic.

\begin{tabular}{|c|c|c|c|c|}
\hline & \multicolumn{4}{|c|}{ Cosine Similarities between the Sustainability Term Distributions between } \\
\hline & $\begin{array}{l}\text { Left in Position and } \\
\text { Right in Position } \\
\text { (Case i) } \\
\text { (1) }\end{array}$ & $\begin{array}{l}\text { Left in Opposition } \\
\text { and Right in } \\
\text { Opposition } \\
\text { (Case ii) } \\
\text { (2) }\end{array}$ & $\begin{array}{l}\text { Left in Opposition } \\
\text { and Left in Position } \\
\text { (Case iii) } \\
\text { (3) }\end{array}$ & $\begin{array}{l}\text { Right in Opposition } \\
\text { and Right in Position } \\
\text { (Case iv) } \\
\text { (4) }\end{array}$ \\
\hline Agreements with EU & 0.6642 & 0.7989 & 0.2594 & 0.3074 \\
\hline $\begin{array}{l}\text { Regulation of number } \\
\text { of reindeer }\end{array}$ & 0.8465 & 0.8899 & 0.8443 & 0.8895 \\
\hline $\begin{array}{l}\text { Co-operation in the } \\
\text { Arctic }\end{array}$ & 0.9995 & 0.9838 & 0.9998 & 0.9891 \\
\hline Cod fishery & 0.9899 & 0.8122 & 0.8643 & 0.9870 \\
\hline $\begin{array}{l}\text { Ocean management } \\
\text { plan }\end{array}$ & 0.6346 & 0.9864 & 0.9971 & 0.6381 \\
\hline Petroleum politics & 0.6524 & 0.2312 & 0.5526 & 0.3483 \\
\hline $\begin{array}{c}\text { Reindeer husbandry } \\
\text { agreement }\end{array}$ & 0.8201 & 0.9528 & 0.9178 & 0.7206 \\
\hline Business development & 0.9450 & 0.9921 & 0.9404 & 0.9991 \\
\hline Aquaculture & 0.8816 & 0.9177 & 0.7624 & 0.9717 \\
\hline Svalbard & 0.9639 & 0.9526 & 0.5390 & 0.2856 \\
\hline
\end{tabular}


When it comes to cases i) and ii), we can read from columns (1) and (2) in Table 6 that the cosine similarities are surprisingly similar between left and right wing when they both are observed in the same role. The only larger difference between the coalitions in the content of sustainability terms is in petroleum politics in opposition, where CS is only 0.23.

To analyze in even more detail how the usage of the sustainability term has differed, we take a look at the differences on the level of individual terms. We show the log probabilities of individual terms in a scatter plot when the coalition is in position and opposition, see Figure 4 . If the term lies over the 45-degree line, the coalition uses it more in position. If it is under the line, the opposite is the case. Observe that the logarithmic scale implies that points to the north-east with the same distance from the 45-degree line as points to the south-west, are much further away than a visual inspection of the plot suggests. Hence, if we are interested in differences more than similarity, the north-east is where to look. The figures speak for themselves. Let us just comment on three extreme examples for illustration.

For the topic petroleum politics, we see that the probability for the right side of using the term sustainable growth in position is much higher than in opposition (66 times higher to be exact). The same probability for the left side in opposition is nine times lower than in position. It seems unreasonable not to interpret these huge differences as more than coincidences. For the topic agreements with EU the probability that the left side uses sustainable growth is 64 times higher when they have governmental responsibility. One reason behind why sustainable harvest is so much more used by the left side is that Stortinget happened to discuss the fishery agreement with EU when the left side parties were in opposition (Fisheries was an important reason why the referenda in Norway over EU membership ended with a «no» two times. Fisheries is clearly an important political issue even for countries where the economic importance is much less than for Norway, as witnessed by the recent confrontations between U.K. and France in the wake of Brexit). Again, although the timing of the debate over the fishery agreement could be an exogenous event affecting the numbers, the magnitude is so large that similar mechanisms as in our first example is not unlikely.

When talking about Svalbard, the probabilities to use the term sustainable utilisation were significantly higher in position than in opposition, 100 times higher for right side parties and 19 times for the left.

These examples of large differences were all related to position-opposition comparisons, keeping political labels constant (case (iii) and case (iv)). This is not without reason since, as we mentioned earlier, the differences related to Left-Right comparisons, keeping role constant (case (i) and case (ii)), are mostly small. Comparing case (i) and (ii) versus case (iii) and (iv) therefore implies that the role (position and opposition) is much more important for distinguishing the two coalitions than the partisan label (Left and Right).

We will elaborate on possible interpretations of the results in the concluding discussion. 


\section{Petroleum}

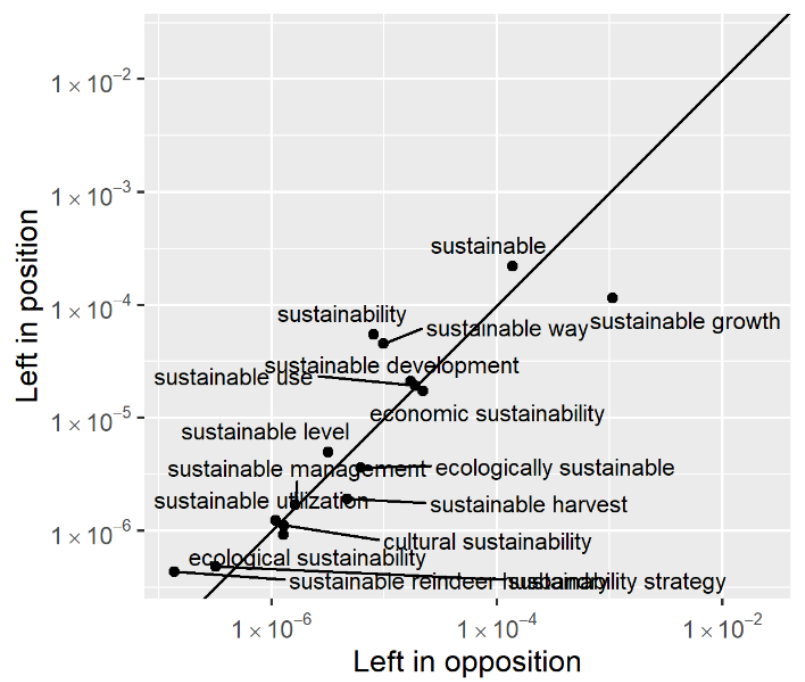

Svalbard

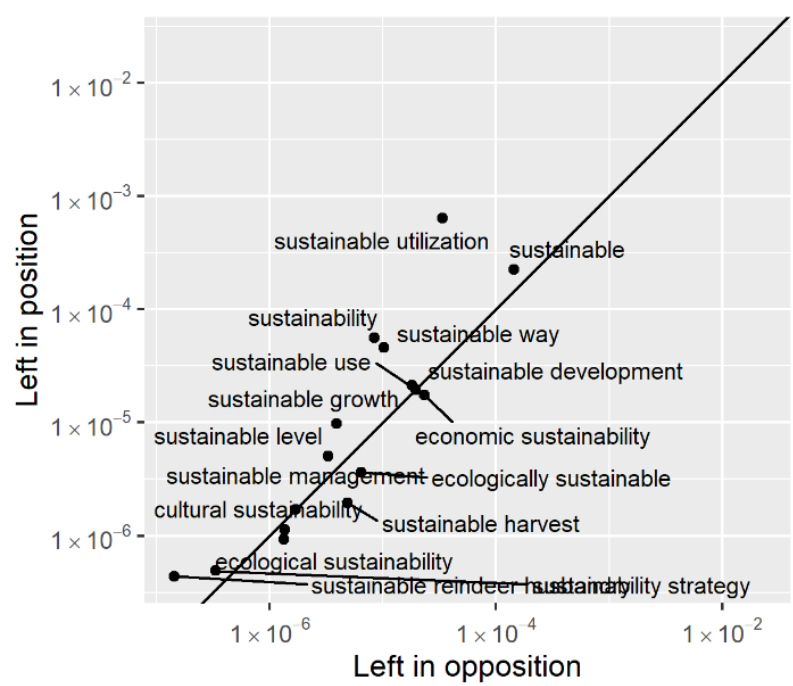

Agreements with EU

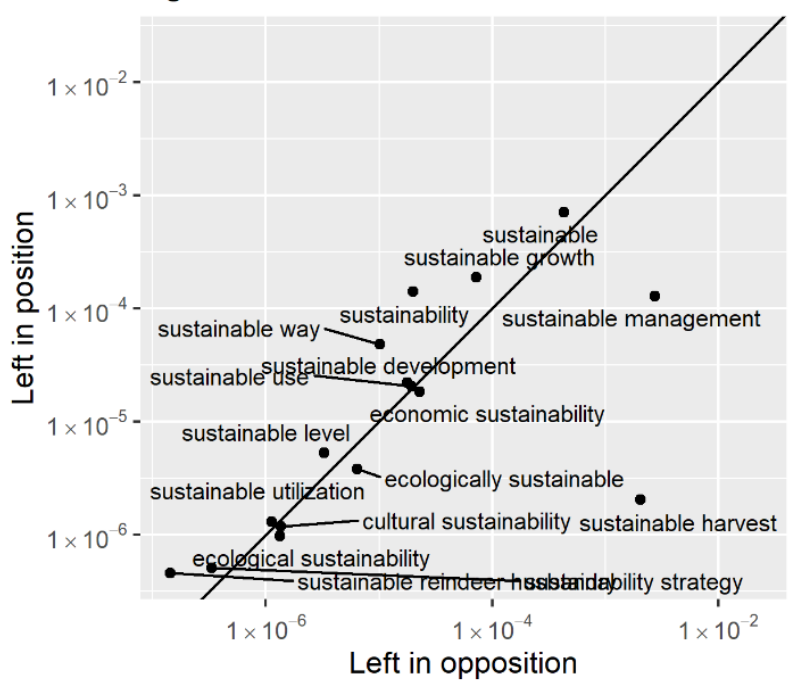

Petroleum

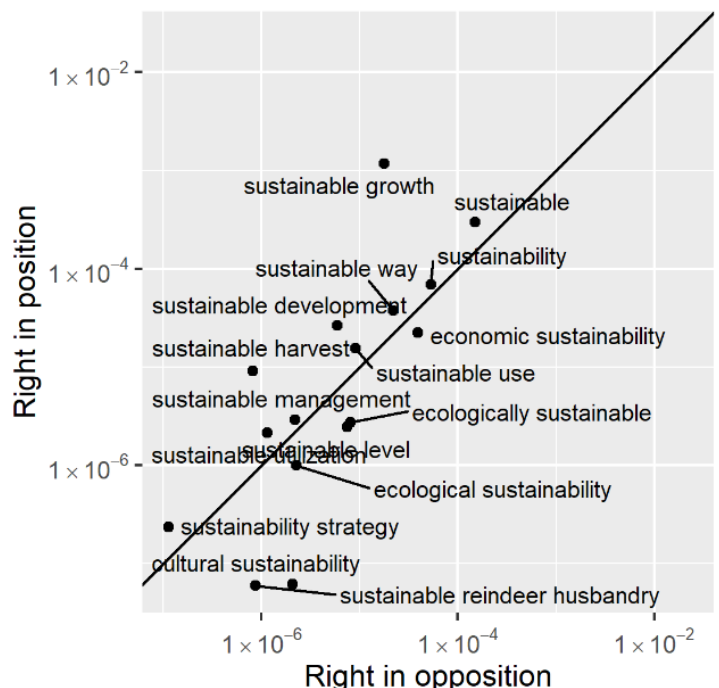

Svalbard

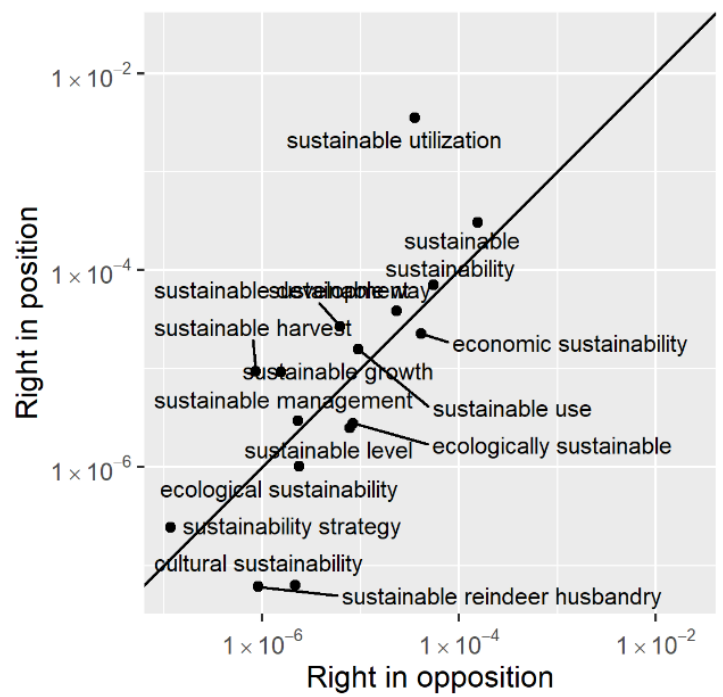

\section{Agreements with EU}

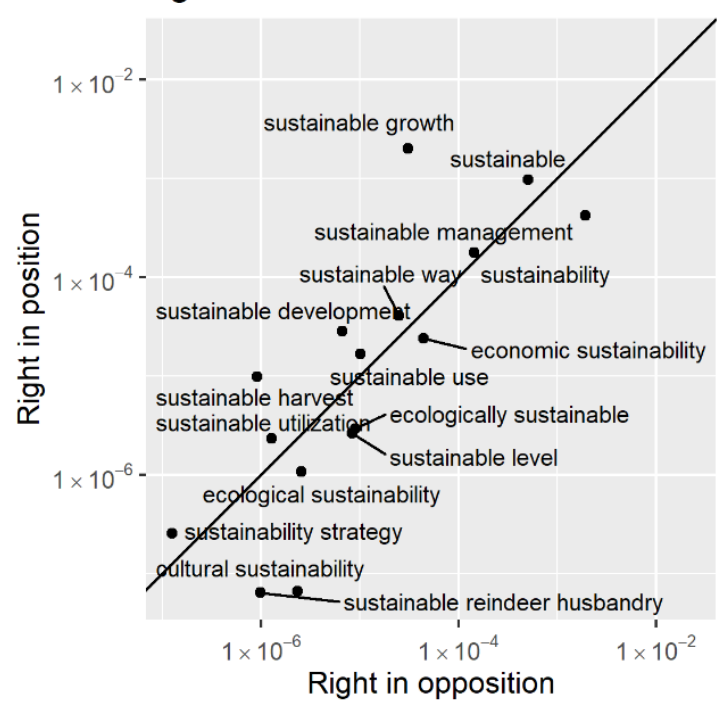

Figure 4. Scatterplots of log probabilities of sustainability terms by selected topic. 


\section{Discussion}

In this paper we have seen that there are considerable differences in how much and in what way left and right coalitions talk about sustainability in the Arctic when in government and in opposition. One naïve interpretation of this observation could be that political parties cannot be trusted. They behave opportunistically and say one thing when they depend on the electorate to replace the incumbent in next election and another thing when in office.

On the other hand, another explanation for what we observe could be genuine political preferences. But the difference between being in position and opposition, controlling for political label (left-right), is far more important than the difference between left and right, controlling for role (opposition-government). The results therefore suggest that in the trade-off between political preferences and election success, the balance is tilted in favour of the latter. Our interpretation is that opportunistic behavior seems to dominate partisan behavior in the politics related to sustainability in the Arctic.

The concept of sustainability is well suited for political greenwashing as its usage comes with a low cost for a politician; the concept is positively charged and semantically diffuse while its policy delivery is very difficult to evaluate and to monitor for voters [8,12]. Aardal [16] found that political parties in Norway effectively engaged in greenwashing more than 30 years ago, by linking environmental issues to their core issues in their political manifestos. Our results show that coalitions in office link sustainability words in parliamentary speeches to their core issues in their government platforms. Norway has an ambitious sustainability policy and profiles itself as a leader in sustainability issues in the Arctic [4]. This profile, together with larger responsibility in office, may incentivize politicians and could explain some of the change in 'sustainability language' when moving from opposition to power.

\section{Conclusions}

In this paper, we have employed unsupervised text mining techniques to analyze parliamentary speeches for Norway from the period 2009 to 2016. We have asked whether political coalitions talk differently about sustainability in the Arctic depending on being in opposition or government. Our main results show that:

1. Both left- and right-wing coalitions talk more about sustainability when in office.

2. Both coalitions change how they speak about sustainability when in government.

3. Both coalitions relate sustainability terms to their core issues.

4. Governmental status is more important for sustainability rhetoric than coalition affiliation.

The general limitation posed by the counterfactual problem is present in our analysis: a party or coalition cannot at the same time be in position and in opposition. There is therefore clearly in principle a possibility that the differences observed may, at least in part, be attributed to exogenous events that change the context from one period to the next. For example, we found that the left used sustainable harvest much more talking about the topic agreements with $E U$ when in position compared to in opposition. However, this coincided with the important discussion with EU over the fishery agreement. If this event had not taken place in the first period, but the second period when the left was in opposition, results could have been different, if not qualitatively, at least quantitatively.

To the extent that exogenous events are not unique, but may repeat themselves over time, a longer time frame could to some degree mitigate the counterfactual problem. We believe that extending the present analysis in time and space would be interesting not only as a check on generalizability, but also to allow new dimensions for comparison. Within the present national context, going one period further back and one period more ahead, would permit a comparison of the left in power for two consecutive periods (the Stoltenberg II and III cabinets) followed by the right also for two consecutive periods (the Solberg I and II cabinets). It could also be interesting to put things in a longer time perspective, maybe 
by going all the way back to the period when Gro Harlem Brundtland became the first minister of the environment (appointed in 1974 during the Bratteli II Labour cabinet).

From an international circumpolar comparative perspective, it would clearly be even more exciting to extend the analysis, not only in time but also in space by including more Arctic countries. Similar data sources, that we have used for Norway, now exist at least for Canada, Iceland, Sweden and Finland. These Arctic countries have different parliamentary systems, as well as costs related to achieve both economic, ecologic, and social sustainable development goals. The different difficulties to reach development goals and different institutional setups will most likely lead to different rhetoric emphasis when it comes to the usage of sustainability concepts and the incentives for greenwashing. To throw more light on these issues, future research could amalgamate study of sustainability rhetoric together with sustainability policy delivery evaluation (see, for example, [39]). We hope that our article can stimulate further research in this direction, taking advantage of the new data available.

All in all, this study has demonstrated that topic modelling is a promising approach worth exploring further in the context of how political actors strategically deal with societal challenges, as large databases of parliamentary speeches and debates are made more and more accessible.

Supplementary Materials: The following are available online at https:/ /www.mdpi.com/article/10 $.3390 / \mathrm{su1} 13169397 / \mathrm{s} 1$, Basic structural model, Figure S1. Scatterplots of log probabilities of sustainability terms by selected topic.

Author Contributions: Conceptualization, M.M. and S.Ø.; methodology, M.M. and S.Ø.; software, M.M.; writing — original draft preparation, M.M. and S.Ø.; writing—review and editing, M.M. and S.Ø. All authors have read and agreed to the published version of the manuscript.

Funding: This research received no external funding.

Informed Consent Statement: Not applicable.

Data Availability Statement: Data is publicly available at https://github.com/ltgoslo/talk-ofnorway. (accessed on 16 April 2021).

Conflicts of Interest: The authors declare no conflict of interest.

\section{References}

1. Box, J.E.; Colgan, W.T.; Christensen, T.R.; Schmidt, N.M.; Lund, M.; Parmentier, F.-J.W.; Brown, R.; Bhatt, U.S.; Euskirchen, E.S.; Romanovsky, V.E.; et al. Key indicators of Arctic climate change: 1971-2017. Environ. Res. Lett. 2019, 14, 45010. [CrossRef]

2. Landrum, L.; Holland, M.M. Extremes become routine in an emerging new Arctic. Nat. Clim. Chang. 2020, 10, 1108-1115. [CrossRef]

3. Spohr, K.; Hamilton, D.S.; Moyer, J.C. The Arctic and World Order; Foreign Policy Institute: Washington, DC, USA, 2020.

4. Norwegian Ministry of Foreign Affairs. The Norwegian Government's Arctic Policy; 2021. Available online: https:/ / www.regjeringen. no/en/dokumenter/arctic_policy/id2830120/(accessed on 21 August 2021).

5. Gad, U.P.; Strandsbjærg, J. Sustainability as a political concept in the Arctic. In The Political Sustainability in the Arctic: Reconfiguring Identity, Space, and Time; Gad, U.P., Strandsbjærg, J., Eds.; Routledge: London, UK; New York, NY, USA, 2019; pp. 1-18.

6. MacNeill, J. The forgotten imperative of sustainable development. Environ. Policy Law 2006, 36, 167-170.

7. Orwell, G. 1984; Secker and Warburg: London, UK, 1949.

8. Fleig, A.; Tosun, J. Political Parties' Rhetoric Signaling of Sustainable Development. Sustain. Dev. 2017, 25, 431-442. [CrossRef]

9. Kagawa, F. Dissonance in students' perceptions of sustainable development and sustainability. Int. J. Sustain. High. Educ. 2007, 8, 317-338. [CrossRef]

10. Clarke, M.; Islam, S.M.N. National account measures and sustainability objectives: Present approaches and future prospects. Sustain. Dev. 2006, 14, 219-233. [CrossRef]

11. Cislak, A.; Cichocka, A.; Wojcik, A.D.; Milfont, T.L. Words not deeds: National narcissism, national identification, and support for greenwashing versus genuine proenvironmental campaigns. J. Environ. Psychol. 2021, 74, 101576. [CrossRef]

12. Seele, P.; Gatti, L. Greenwashing Revisited: In Search of a Typology and Accusation-Based Definition Incorporating Legitimacy Strategies. Bus. Strategy Environ. 2017, 26, 239-252. [CrossRef]

13. Stoknes, P.E.; Rockström, J. Redefining green growth within planetary boundaries. Energy Res. Soc. Sci. 2018, 44, 41-49. [CrossRef]

14. Stevenson, H. Reforming global climate governance in an age of bullshit. Globalizations 2021, 18, 86-102. [CrossRef]

15. Giddens, A. Politics of Climate Change; Polity: Cambridge, UK, 2009. 
16. Aardal, B. Energi og Miljø: Nye Stridsspørsmål i Møte Med Gamle Strukturer; Institutt for Samfunnsforskning: Oslo, Norway, 1993.

17. Jensen, L.C. Norwegian petroleum extraction in Arctic waters to save the environment: Introducing 'discourse co-optation' as a new analytical term. Crit. Discourse Stud. 2012, 9, 29-38. [CrossRef]

18. Hibbs, D.A., Jr. Political parties and macroeconomic policy. Am. Political Sci. Rev. 1977, 71, 1467-1487. [CrossRef]

19. Nordhaus, W.D. The Political Business Cycle. Rev. Econ. Stud. 1975, 42, 169-190. [CrossRef]

20. Dubois, E. Political business cycles 40 years after Nordhaus. Public Choice 2016, 166, 235-259. [CrossRef]

21. Shiller, R.J. Narrative Economics. Am. Econ. Rev. 2017, 107, 967-1004. [CrossRef]

22. Evans, J.A.; Aceves, P. Machine Translation: Mining Text for Social Theory. Annu. Rev. Sociol. 2016, 42, 21-50. [CrossRef]

23. Gentzkow, M.; Kelly, B.; Taddy, M. Text as Data. J. Econ. Lit. 2019, 57, 535-574. [CrossRef]

24. Grimmer, J.; Stewart, B.M. Text as Data: The Promise and Pitfalls of Automatic Content Analysis Methods for Political Texts. Political Anal. 2013, 21, 267-297. [CrossRef]

25. WCED. Our Common Future, Report from the 'Brundtland' World Commission on Environment and Development; Oxford University Press: Oxford, UK, 1987.

26. Søyland, M. Parliamentary Debates in Norway: A Computational Social Science Approach. Ph.D. Thesis, University of Oslo, Oslo, Norway, 2020.

27. Proksch, S.-O.; Slapin, J.B. The Politics of Parliamentary Debate: Parties, Rebels and Representation; Cambridge University Press: Cambridge, UK, 2014.

28. Roberts, M.E.; Stewart, B.M.; Tingley, D. stm: An R Package for Structural Topic Models. J. Stat. Softw. 2019, 91, 40. [CrossRef]

29. Abercrombie, G.; Batista-Navarro, R. Sentiment and position-taking analysis of parliamentary debates: A systematic literature review. J. Comput. Soc. Sci. 2020, 3, 245-270. [CrossRef]

30. Finseraas, H.; Høyland, B.; Søyland, M.G. Climate politics in hard times: How local economic shocks influence MPs attention to climate change. Eur. J. Political Res. 2021, 60, 738-747. [CrossRef]

31. Lapponi, E.; Søyland, M.G.; Velldal, E.; Oepen, S. The Talk of Norway: A richly annotated corpus of the Norwegian parliament, 1998-2016. Lang. Resour. Eval. 2018, 52, 873-893. [CrossRef]

32. Rose, S.; Engel, D.; Cramer, N.; Cowley, W. Automatic Keyword Extraction from Individual Documents. In Text Mining: Applications and Theory; Berry, M.W., Kogan, J., Eds.; John Wiley \& Sons: Chichester, UK, 2010; pp. 1-20.

33. Roberts, M.E.; Stewart, B.M.; Airoldi, E.M. A Model of Text for Experimentation in the Social Sciences. J. Amer. Stat. Assoc. 2016, 111, 988-1003. [CrossRef]

34. Blei, D.M.; Ng, A.Y.; Jordan, M.I. Latent dirichlet allocation. J. Mach. Learn. Res. 2003, 3, 993-1022.

35. Blei, D.M.; Lafferty, J.D. A correlated topic model of Science. Ann. Appl. Stat. 2007, 1, 17-35. [CrossRef]

36. Government of Prime Minister Erna Solberg. The Sundvolden Platform for a Government Formed by the Conservative Party and the Progress Party; 2013. Available online: https://www.regjeringen.no/contentassets/a93b067d9b604c5a82bd3b5590096f74/ politisk_platform_eng.pdf (accessed on 21 August 2021).

37. Government of Norway. Soria Moria Declaration II 2009-2013; 2008. Available online: https:/ /www.regjeringen.no/globalassets / upload/smk/vedlegg/2005/regjeringsplatform_soriamoria.pdf (accessed on 21 August 2021).

38. Burggraaff, C.; Trilling, D. Through a different gate: An automated content analysis of how online news and print news differ. Journalism 2020, 21, 112-129. [CrossRef]

39. Sala, S.; Ciuffo, B.; Nijkamp, P. A systemic framework for sustainability assessment. Ecol. Econ. 2015, 119, 314-325. [CrossRef] 